\title{
On the Mechanism of the Skraup-Doebner-Von-Miller Quinoline Synthesis
}

\author{
Scott E. Denmark* and Srikanth Venkatraman \\ Roger Adams Laboratory, Department of Chemistry, University of Illinois, Urbana, IL 61801
}

\section{SUPPORTING INFORMATION}

General Information

Method for Calculation of Isotope Scrambling

Synthesis of Quinoline 3, labeled mesityl oxide, control and crossover experiments

\section{General Information}

All reactions were performed in oven $\left(140{ }^{\circ} \mathrm{C}\right)$ or flame-dried glassware under an inert atmosphere of dry $\mathrm{N}_{2}$. All reaction temperatures corresponded to internal temperatures unless otherwise noted. Solvents for extraction and chromatography were technical grade and distilled from the indicated drying agents: hexane $\left(\mathrm{CaCl}_{2}\right)$; methylene chloride $\left(\mathrm{CaCl}_{2}\right)$; ethyl acetate $\left(\mathrm{K}_{2} \mathrm{CO}_{3}\right)$. Reaction solvents were distilled from the indicated drying agents: methylene chloride $\left(\mathrm{P}_{2} \mathrm{O}_{5}\right)$; diethyl ether (sodium, benzophenone); hexane (sodium); tetrahydrofuran (THF) (sodium, benzophenone); and toluene (sodium). Flash column chromatography was performed by the method of Still, ${ }^{1}$ using 230-400 mesh silica gel purchased from EM Science. TLC was performed on Merck silica gel plates with QF-254 indicator. Plates were visualized using UV radiation $(254 \mathrm{~nm})$ in conjunction with the following reagents: $\mathrm{KMnO}_{4}$ (alkenes, quinolines, anilines), anisaldehyde and vanillin, 2,4-dinitrophenylhydrazine (aldehydes and ketones), and $\mathrm{I}_{2}$ (alkenes, aromatics). $n$-Butyllithium was titrated according to the method of Gilman. ${ }^{2}$

${ }^{1} \mathrm{H}$ NMR, ${ }^{13} \mathrm{C} \mathrm{NMR},{ }^{31} \mathrm{P}$ spectra were recorded at $400 \mathrm{MHz},{ }^{1} \mathrm{H} ; 100 \mathrm{MHz},{ }^{13} \mathrm{C}$ ), or 500 
$\left.\mathrm{MHz},{ }^{1} \mathrm{H} ; 126 \mathrm{MHz},{ }^{13} \mathrm{C}\right)$ in deuteriochloroform $\left(\mathrm{CDCl}_{3}\right)$, deuteriobenzene $\left(\mathrm{C}_{6} \mathrm{D}_{6}\right)$, or deuteriomethanol $\left(\mathrm{CD}_{3} \mathrm{OD}\right)$ with either tetramethylsilane (TMS) $\left(0.00 \mathrm{ppm}{ }^{1} \mathrm{H}, 0.00 \mathrm{ppm}{ }^{13} \mathrm{C}\right)$, chloroform $\left(7.27 \mathrm{ppm}{ }^{1} \mathrm{H}, 77.0 \mathrm{ppm}{ }^{13} \mathrm{C}\right)$, benzene $\left(7.15 \mathrm{ppm}{ }^{1} \mathrm{H}, 128.0 \mathrm{ppm}{ }^{13} \mathrm{C}\right)$, or DMSO $\left(2.49 \mathrm{ppm}{ }^{1} \mathrm{H}, 39.5 \mathrm{ppm}{ }^{13} \mathrm{C}\right.$ ) as an internal reference unless otherwise stated. Chemical shifts are given in ppm (d); multiplicities are indicated by s (singlet), d (doublet), $\mathrm{t}$ (triplet), q (quartet), $\mathrm{m}$ (multiplet) or br (broadened). Coupling constants, $J$, are reported in Hertz and the assignment is indicated. ${ }^{1} \mathrm{H}$ and ${ }^{13} \mathrm{C}$ NMR assignments are corroborated by 2D experiments (HETCOR and COSY). Spectra are available on request from denmark@scs.uiuc.edu.

Low-resolution electron impact (EI) mass spectra were obtained with a typical ionization voltage of $70 \mathrm{eV}$. Low resolution fast bombardment (FAB) spectra were obtained using magic bullet (3/1, dithiothreitol/dithioerythiol or 3-nitrobenzyl alcohol). Chemical ionization (CI) spectra were performed using methane as the carrier gas. FI spectra were obtained on a 70-VSEA spectrometer with a source temperature of $150-200{ }^{\circ} \mathrm{C}$. Integration of mass spectral peaks was an average of three independent runs. Data are reported in the form $\mathrm{m} / \mathrm{z}$ (intensity relative to base $=100$ ). Infrared spectra (IR) are reported in $\mathrm{cm}^{-1}$ with the following relative intensities: $\mathrm{s}$ (strong, 67-100\%), m (medium, 34-66\%), w (weak, 0-33\%). Optical rotation was recorded five wavelenghts $(589,577,546,435,405 \mathrm{~nm})$. A plot of $1 / \alpha$ vs $\lambda^{2}$ is drawn and the optical rotation at $589 \mathrm{~nm}$ is calculated from equation of the line in the graph. Bulb-to-bulb distillations were done on a Kugelrohr apparatus; boiling points (bp) refer to air bath temperatures and are uncorrected. Melting points were taken in sealed tubes and are corrected.

Method for Calculation of Isotope Scrambling. The extent of scrambling was calculated using a matrix calculation program. The areas for the $\mathrm{M}^{+}$and higher peaks for the molecule is first obtained at natural abundance. Similarly the area for the $\mathrm{M}^{+}$and higher peaks are obtained for the isotopically enriched molecule. The program uses the Gauss-Jordan or Gauss Seigal method of matrix diagonalization to obtain the eigen value such that it finds the best isotopic distribution that would generate the mass spectral pattern of the labeled species. This calculation could also be done manually by subtracting the contribution of the area of the $(\mathrm{M}+1)$ peak from the $\mathrm{M}^{+}$peak, the contribution of the $(\mathrm{M}+2)$ peak from $(\mathrm{M}+1)$ peak and so on to obtain the scrambling distribution. The program also takes into consideration the contribution of the (M-1) peak. 


\section{Literature Preparations}

${ }^{13} \mathrm{C}(2)$ labeled mesityl oxide was prepared following the method of Frangopal. ${ }^{3}$ Double labeled ${ }^{13} \mathrm{C}(2,4)$ mesityl oxide was achieved using the method developed by Wayne and Adkins. ${ }^{4}$ Triply labeled pulegone was synthesized following the procedure of Corey and Chen. ${ }^{5}$ 2-Bromo-4-isopropylacetanilide was prepared by the method of Sterling. ${ }^{6}$

\section{Procedures}

\section{1,2-Dihydro-6-isopropyl-2,2,4-trimethyl-quinoline (3). A solution of 4-} isopropylaniline (500 mg, $3.7 \mathrm{mmol})$, mesityl oxide ( $725 \mathrm{mg}, 7.3 \mathrm{mmol}, 2.0$ equiv) and iodine (10 mg, $0.037 \mathrm{mmol} 1 \mathrm{~mol} \%$ ) in $2 \mathrm{~mL}$ of dry toluene was heated at reflux under $\mathrm{N}_{2}$ for $5 \mathrm{~h}$. The dark brown reaction mixture was concentrated in vacuo at $50{ }^{\circ} \mathrm{C}$ and the crude residue was purified by silica gel chromatography (hexanes/EtOAc, 24/1) to yield $\mathbf{3}$ as a colorless pale yellow liquid (303 mg, 38\%).

Alternate Procedure. A solution of 4-isopropylaniline $(2.0 \mathrm{~g}, 14.8 \mathrm{mmol})$ and iodine (45 mg, $0.18 \mathrm{mmol}, 1.25 \mathrm{~mol} \%$ ) in a 3-necked, round bottom flask was attached with a Vigreaux column and a distillation set up. Acetone $(10 \mathrm{~mL}, 7.91 \mathrm{~g}, 136.2 \mathrm{mmol}, 9.2$ equiv) was introduced dropwise over $2 \mathrm{~h}$ through a second neck with a dropping funnel while maintaining the internal temperature at $150{ }^{\circ} \mathrm{C}$. The unreacted acetone distilled out. Once the addition of acetone was complete the reaction mixture was concentrated in vacuo and the reaction mixture was purified by silica gel chromatography (hexanes/EtOAc, 24/1) to afford the quinoline product as a colorless liquid. The chromatographed liquid was further purified by Kugelrohr distillation (1.8 g, 60\%). A substantial portion of the quinoline product polymerizes on distillation; bp: 180 (0.01 mm Hg, ABT); $R_{f} 0.68$ (hexane/EtOAc, 7/2); ${ }^{1} \mathrm{H}$ NMR (400 MHz): 6.93 (d, $J=1.9,1 \mathrm{H}, \mathrm{Ar}-$ $\mathrm{HC}(7)) ; 6.87(\mathrm{dd}, J=2.0,7.9,1 \mathrm{H}, \operatorname{Ar} \operatorname{HC}(9)) ; 6.40\left(\mathrm{~d}, J=8.0,1 \mathrm{H}, \operatorname{ArHC}\left(10^{\prime}\right)\right) ; 5.31(\mathrm{~d}, J=$ 0.81, $\mathrm{HC}(3)$ ); 3.6 (br s, $1 \mathrm{H}, \mathrm{HN}(1)$ ); 2.80 (s, $J=6,1 \mathrm{H}, \mathrm{HC}(14)$ ); 2.01 (d, $3 \mathrm{H}, \mathrm{H} 3 \mathrm{C}(13)$ ); 1.28 (s, $\left.6 \mathrm{H}, 2 \times \mathrm{H}_{3} \mathrm{C}(12,13)\right) ; 1.22$ (d, $J=6.8,6 \mathrm{H}, 2 \mathrm{x} \mathrm{H}_{3} \mathrm{CC}(15,16)$ ); ${ }^{13} \mathrm{C} \mathrm{NMR}:(126 \mathrm{MHz}) 141.24$ (C(6)); $137.5(\mathrm{C}(8)) ; 128.6(\mathrm{C}(3)) ; 128.4(\mathrm{C}(4)) ; 126.1(\mathrm{C}(9)) ; 121.7(\mathrm{C}(7)) ; 121.3(\mathrm{C}(5)) ; 112.8$ (C(10)); 51.8 (C(2)); 33.5 (C(14)); 31.1 (C(11,12)); 24.3 (C(15, 16)); 18.7 (C(13)); IR (neat): 3450 (s); 2958 (s); 2932 (s); 2872 (s); 1709 (s); 1492 (m); 1465 (m); 1406 (m); 1380 (m); 1328 (m); 1127 (m); 1097 (m); 1075 (m); 1011 (s); 750 (s); 700 (s); MS (EI, 70 eV) 200([M-CH3] $]^{+}$, 
11); 168 (15); 158 (5); 141 (20); 128.1 (15); 115 (25); 91 (23); 77 (100); 65 (19). FI MS (150): $\left(\mathrm{M}^{+}, 100\right)$; Analysis $\left(\mathrm{C}_{15} \mathrm{H}_{21} \mathrm{~N}(215.15)\right)$ Calcd: $\mathrm{C}, 83.73 \%$; $\mathrm{H}, 9.76 \% \mathrm{~N}, 6.50 \%$. Found: $\mathrm{C}$, $83.73 \%$; H, 9.79\% N, 6.39\%

Synthesis of ${ }^{13} \mathbf{C}$ (2) Labeled Mesityl Oxide (2). A solution of acetyl chloride $\left(10 \%{ }^{13} \mathrm{C}\right.$ enriched $2.00 \mathrm{~g}, 25.6 \mathrm{mmol})$, tert-butyl chloride ( $2.40 \mathrm{~g}, 26.08 \mathrm{mmol}, 1$ equiv) was cooled to $0^{\circ} \mathrm{C}$ and anhydrous $\mathrm{AlCl}_{3}(3.40 \mathrm{~g}, 25.75 \mathrm{mmol}, 1$ equiv) was added slowly. The reaction was stirred at $0{ }^{\circ} \mathrm{C}$ for $3 \mathrm{~h}$. and carefully quenched by pouring the reaction mixture into ice water. The aqueous layer was extracted with dichloromethane (3x $30 \mathrm{~mL})$ and the combined organic layer was dried $\left(\mathrm{Na}_{2} \mathrm{SO}_{4}\right)$ and concentrated in vacuo. The crude reaction mixture was purified by silica gel chromatography $\left(\mathrm{CH}_{2} \mathrm{Cl}_{2}\right)$. to yield ${ }^{13} \mathrm{C}(2)$ labeled mesityl oxide as a colorless liquid (908 mg, 36\%). The ${ }^{1} \mathrm{H}$ and ${ }^{13} \mathrm{C}$ NMR data were identical to that of mesityl oxide at natural abundance except for the large intensity of the carbonyl signal.

Synthesis of Quinoline 3 using ${ }^{13} \mathbf{C}$ (2) Labeled Mesityl Oxide. A solution of mesityl oxide (194 mg, $1.97 \mathrm{mmol}, 10$ 13C(2) enriched), 4-isopropylaniline (175 mg, $1.29 \mathrm{mmol}, 1$ equiv) and $\mathrm{I} 2(21 \mathrm{mg}, 0.08 \mathrm{mmol} 1 \mathrm{~mol} \%)$ in $3.4 \mathrm{~mL}$ of toluene was heated at reflux for $8 \mathrm{~h}$. The reaction mixture was concentrated in vacuo and the crude mixture was purified by silica gel chromatography (hexanes/EtOAc, 24/1) to yield 3 as a pale yellow liquid (93 mg, 34\%).

Synthesis of ${ }^{13} \mathbf{C}(2)$ and ${ }^{13} \mathbf{C}(4)$ Labeled Mesityl Oxide. A solution of acetone (98 13 $\mathrm{C}(2)$ labeled, $(1 \mathrm{~g}, 17.24 \mathrm{mmol})$ in benzene $(2 \mathrm{~mL})$ was treated with aluminum tert-butoxide $(2.0$ g $8.1 \mathrm{mmol}, 0.5$ equiv) was heated in a sealed tube at $80-90^{\circ} \mathrm{C}$. The reaction mixture was heated for $8 \mathrm{~h}$ when it turns green and gelatinous. The mixture was cooled and the mixture was quenched with water $(2 \mathrm{~mL})$ and was heated at $70{ }^{\circ} \mathrm{C}$ for $15 \mathrm{~min}$. The mixture was extracted into ether $(50 \mathrm{~mL})$, filtered and the filtrate was dried $\left(\mathrm{Na}_{2} \mathrm{SO}_{4}\right)$, concentrated in vacuo and purified by silica gel chromatography (pentane and /pentane/ether, 13/1) to isolate mesityl oxide (63 mg 8\%). The ${ }^{1} \mathrm{H}$ and ${ }^{13} \mathrm{C}$ NMR data were similar to those of the material at natural abundance. 


\section{Mass spectral analysis of synthetic mesityl oxide.}

\begin{tabular}{|ccccc|}
\hline $\begin{array}{c}\text { mesityl oxide } \\
\text { source }\end{array}$ & $m / z$ 98, \% & $m / z ~ 99, \%$ & $m / z ~ 100, \%$ & $m / z ~ 101, \%$ \\
\hline \hline natural abundance & 100.0 & 7.2 & 0.5 & 0.2 \\
synthetic 13C (2,4) & 0.1 & 2.4 & 100.0 & --- \\
normalized & 0.1 & 2.3 & 97.6 & --- \\
used in cross over experiment & 54.1 & 7.5 & 34.0 & 3.1 \\
Gauss-Jordan Analysis & 59.7 & 3.0 & 36.9 & -- \\
Theoretical 100\% scrambling & 37.7 & 47.4 & 14.9 & -- \\
\hline
\end{tabular}

Synthesis of Quinoline 3 with ${ }^{13} \mathbf{C}(2)$ and ${ }^{13} \mathbf{C ( 4 )}$ Labeled Mesityl Oxide. A solution of mesityl oxide ${ }^{13} \mathrm{C}(2,4)$ labeled mesityl oxide $(70 \mathrm{mg}, 0.51 \mathrm{mmol})$ with a mass distribution of $\mathrm{M}^{+} /(\mathrm{M}+1)^{+} /(\mathrm{M}+2)^{+}: 58.8 \%: 4.00 \%: 37: 1 \%$ in $1.3 \mathrm{~mL}$ of dry toluene was heated at reflux with 4isopropyaniline (70 mg, $0.71 \mathrm{mmol}, 1.39$ equiv) and iodine ( $8.4 \mathrm{mg}, 0.032 \mathrm{mmol}, 6.4 \mathrm{~mol} \%$ ) for $8 \mathrm{~h}$. The reaction mixture was concentrated in vacuo and purified by $\mathrm{SiO}_{2}$ gel chromatography (24:1 hexanes/EtOAc) to yield quinoline as a pale yellow liquid (51 mg, 47\%). The ${ }^{1} \mathrm{H}$ NMR and $13 \mathrm{C}$ NMR data were identical to those from a previously prepared synthetic sample. The mass distribution of the product was analyzed by FI mass spectroscopy.

\section{Mass spectral analysis of the quinoline 3.}

\begin{tabular}{|ccccc|}
\hline $\begin{array}{c}\text { Quinoline } \\
\text { source }\end{array}$ & $m / z 215, \%$ & $m / z 216, \% \mathrm{~m} / z 217, \%$ & $m / z 218, \%$ \\
\hline \hline $\begin{array}{c}\text { natural abundance } \\
\text { cross over experiment }\end{array}$ & 100.0 & 16.5 & 2.2 & 0.5 \\
run 1 & 66.0 & 100.0 & 54.0 & 7.0 \\
run 2 & 62.0 & 100.0 & 50.7 & 6.4 \\
run 3 & 62.1 & 100.0 & 52.3 & 6.8 \\
average & 63.4 & 100.0 & 52.3 & 6.7 \\
normalized & 28.5 & 45.0 & 23.5 & 3.0 \\
Gauss-Jordan Analysis & 33.0 & 47.7 & 18.2 & -- \\
Theoretical 100\% scrambling & 37.7 & 47.4 & 14.9 & -- \\
\hline
\end{tabular}


Control Experiment for Mesityl Oxide Scrambling. A solution of 4-isopropylaniline (202 mg, $1.49 \mathrm{mmol}$ ), mesityl oxide (300 mg, $3.06 \mathrm{mmol}, 2$ equiv, $20 \%{ }^{13} \mathrm{C}(2)$ enriched) and iodine $(19.2 \mathrm{mg}, 0.075 \mathrm{mmol}, 5 \mathrm{~mol} \%)$ was heated at reflux in toluene $(2.0 \mathrm{~mL})$ for $1 \mathrm{~h}$. The reaction mixture was cooled to room temperature and directly adsorbed on $\mathrm{SiO}_{2}$ and chromatographed (ether/pentanes 1:25) to yield quinoline (100 mg 31\%) and unreacted mesityl oxide $\left(41.3 \mathrm{mg} 13.9 \%\right.$, concentrate at $\left.0^{\circ} \mathrm{C}\right)$. The ${ }^{1} \mathrm{H}$ and ${ }^{13} \mathrm{C}$ NMR spectra of both quinoline and mesityl oxide were identical to a previously prepared sample. The quinoline spectrum showed ${ }^{13} \mathrm{C}$ enrichment at $\delta 51.8$, and 128.6 . in equal intensity. The $\mathrm{C}(4)$ position of mesityl oxide was also partially enriched (10-15\%).

Control Experiment for Quinoline Scrambling. A solution of quinoline 3 (100 mg, $0.47 \mathrm{mmol}$ ), mesityl oxide (98 mg, $1.0 \mathrm{mmol}, 2.0$ equiv, $20 \%{ }^{13} \mathrm{C}(2)$ enriched) and iodine (6.0 $\mathrm{mg}, 0.023 \mathrm{mmol}, 5 \mathrm{~mol} \%)$ in toluene $(1.0 \mathrm{~mL})$ was heated at reflux for $4 \mathrm{~h}$. The reaction mixture was cooled to room temperature and the mixture was concentrated in vacuo and the residue was purified by $\mathrm{SiO}_{2}$ gel chromatography (pentanes/ether, 20/1) to yield quinoline (91 mg 91\%) as a pale yellow oil and mesityl oxide (26.2 mg 26\%) as a colorless oil. ${ }^{1} \mathrm{H}$ and ${ }^{13} \mathrm{C}$ NMR data from the quinoline product were identical to those from a previously synthesized sample and showed no ${ }^{13} \mathrm{C}$ incorporation.

Preparation of 3-Methylcyclohexanone (25) [3-(methyl-13 C)]. A solution of ${ }^{13} \mathrm{C}$ methyllithium $(24.0 \mathrm{~mL}, 0.6 \mathrm{M}$ solution in ether, $14.4 \mathrm{mmol}$ ) was added dropwise to a suspension of $\mathrm{PhSCu}\left(2.47 \mathrm{~g}, 14.4 \mathrm{mmol}, 1\right.$ equiv) in dry ether $(10 \mathrm{~mL})$ at $-78^{\circ} \mathrm{C}$. The reaction mixture was stirred at $-78^{\circ} \mathrm{C}$ for $1 \mathrm{~h}$ and $-20^{\circ} \mathrm{C}$ for $20 \mathrm{~min}$. The cuprate formed was cooled to $78^{\circ} \mathrm{C}$ and treated with a solution of 2-cyclohexeneone (1.38 g, $14.4 \mathrm{mmol}, 1$ equiv) in ether (10 $\mathrm{mL}$ ) dropwise. The solution was slowly allowed to warm to room temperature and treated with $\mathrm{MeOH}(3.0 \mathrm{~mL})$. The reaction mixture was filtered and the solid was thoroughly washed with ether. The filtrate was concentrated in vacuo $\left(0^{\circ} \mathrm{C}\right)$ and the residue was chromatographed on silica gel (pentane/ether 12/1) to yield 3-methyl-2-cyclohexanone (1.18 g, 72\%). The spectral data were identical to those from an earlier prepared sample except $(J(13 \mathrm{CH})=125 \mathrm{~Hz})$.

Preparation of Dithio Ketene Acetal 26: 2-[Bis(methylthio)methylene]-5-methylCyclohexanone, [5-(methyl-13C)]. A solution of 2,6-tert-butyl-4-methylphenol (3.75g, 17.04 $\mathrm{mmol})$ in ether $(20 \mathrm{~mL})$ was cooled to $-40^{\circ} \mathrm{C}$ and treated slowly with a solution of n-BuLi (10.5 
$\mathrm{mL}, 1.6 \mathrm{M}$ solution in hexanes, $16.8 \mathrm{mmol}, 1$ equiv.). The reaction mixture was slowly warmed to room temperature when the white precipitate formed dissolves to give a clear solution. This solution was then treated dropwise with a solution of $\left({ }^{13} \mathrm{C}\right)$-3-methylcyclohexanone (896 $\mathrm{mg}, 8.0$ mmol, 0.5 equiv) and carbon disulfide $(3.23 \mathrm{~g}, 42.5 \mathrm{mmol}, 5.3 \mathrm{equiv})$ in ether $(25.0 \mathrm{~mL})$. The reaction mixture turns bright yellow and orange on stirring the reaction mixture at room temperature for $9.5 \mathrm{~h}$. A solution of methyl iodide (3.06 g, $21.5 \mathrm{mmol}, 2.69$ equiv.) in ether (10 $\mathrm{mL}$ ) was added and the resulting mixture was stirred at room temperature for an additional $12 \mathrm{~h}$. The reaction mixture was diluted with $\mathrm{H}_{2} \mathrm{O}(100 \mathrm{~mL})$ and the aqueous layer was extracted with ether $(3 \times 50 \mathrm{~mL})$. The combined organic layer were dried $\left(\mathrm{Na}_{2} \mathrm{SO}_{4}\right)$ and concentrated in vacuo. The dark orange residue was chromatographed on silica gel with pentanes to remove the phenol and further chromatographed with ether/pentanes $8 / 1$ to obtain the dithio ketene acetal (500 mg $29 \%$ ) as a pale yellow liquid.

\section{Synthesis of Triple Labeled Pulegone 16: (5-Methyl-2-(1-methylethylidene)-2-} cyclohexanone, [5-(methyl-13 C), 1-(methyl-13C-)-1-(ethylidine-13 C)). A suspension of $\mathrm{PhSCu}\left(670 \mathrm{mg}, 3.90 \mathrm{mmol}, 2.5\right.$ equiv.) in dry THF $(4.0 \mathrm{~mL})$ was cooled to $-78^{\circ} \mathrm{C}$ and treated with ${ }^{13} \mathrm{CH}_{3} \mathrm{Li}(0.56 \mathrm{M}$ in ether, $7.0 \mathrm{~mL}, 3.92 \mathrm{mmol}, 2.5$ equiv.). The reaction mixture was stirred at $-78^{\circ} \mathrm{C}$ for $1 \mathrm{~h}$ and $-20^{\circ} \mathrm{C}$ for $20 \mathrm{~min}$. The reaction mixture was cooled to $-78^{\circ} \mathrm{C}$ and treated with a solution of dithio ketene acetal (340 mg, $1.57 \mathrm{mmol}, 1.0$ equiv). The clear mixture turned opaque with the precipitation of $\mathrm{PhSCu}$. The reaction mixture was warmed to room temperature and the mixture was treated with methanol $(15.0 \mathrm{~mL})$. The reaction mixture was diluted with sat. aq. $\mathrm{NH}_{4} \mathrm{Cl}$ solution $(25.0 \mathrm{~mL})$ and the aqueous layer was extracted with ether (3 X $30 \mathrm{~mL}$ ). The combined ether layers were concentrated in vacuo and the mixture was separated by silica gel chromatography (pentane/ether 19/1) to afford pulegone (188 $\mathrm{mg}, 79 \%$ ) as a yellow oil. The ${ }^{1} \mathrm{H}$ and ${ }^{13} \mathrm{C}$ NMR spectra data were identical to those of the natural material. The mass distribution of synthetic pulegone was evaluated by FI mass spectrometry. 


\section{Mass spectral analysis of synthetic pulegone.}

\begin{tabular}{|c|c|c|c|c|c|}
\hline $\begin{array}{c}\text { pulegone } \\
\text { source }\end{array}$ & $\begin{array}{c}m / z 152 \\
\%\end{array}$ & $\begin{array}{c}m / z 153 \\
\% \\
\end{array}$ & $\begin{array}{c}m / z 154 \\
\% \\
\end{array}$ & $\begin{array}{c}m / z 155, \\
\%\end{array}$ & $\begin{array}{c}m / z 156 \\
\% \\
\end{array}$ \\
\hline natural abundance & 87.8 & 11.2 & 0.9 & & \\
\hline synthetic ${ }^{13} \mathrm{C}(2,4)$ & & & 2.7 & 100.0 & 11.3 \\
\hline synthetic ${ }^{13} \mathrm{C}(2,4)$, normalized & & & 2.4 & 87.7 & 9.9 \\
\hline used in cross over experiment & 44.0 & 4.2 & 1.5 & 45.2 & 5.1 \\
\hline Gauss-Jordan Analysis & 48.0 & 0.0 & 1.3 & 49.2 & --- \\
\hline Theoretical $100 \%$ scrambling & 24.2 & 25.0 & 25.0 & 25.9 & --- \\
\hline
\end{tabular}

Synthesis of Quinolines 22a and 22b: (3R)-6'-Isopropyl-3,4'-dimethylspiro[cyclohexane-1,2'(1'H)-quinoline]. A solution of 4-isopropylaniline $(0.50 \mathrm{~g}, 3.70 \mathrm{mmol})$ (R)-pulegone ( $0.70 \mathrm{~g}, 4.625 \mathrm{mmol}, 1.25$ equiv, tech. grade) and iodine (19 $\mathrm{mg}, 0.08 \mathrm{mmol} 2$ mol\%) was heated to reflux in toluene $(5.0 \mathrm{~mL})$ for $13 \mathrm{~h}$. The dark brown solution was concentrated in vacuo and the residue was purified by silica gel chromatography (hexanes/ether 6/1) to provide $206 \mathrm{mg}$ (21\%) of 22a and $200 \mathrm{mg}(20 \%)$ of $\mathbf{2 2 \mathbf { b }}$ as pale-yellow, viscous oils. Data for 22a: $R_{f}=0.69$ (hexane/ether, $\left.6 / 1\right) ;[\alpha]_{\mathrm{D}}-51.3\left(\mathrm{c}=1.05, \mathrm{CHCl}_{3}\right) ;{ }^{1} \mathrm{H} \mathrm{NMR}(500 \mathrm{MHz}$, d4-methanol): 6.87 (d, $1 \mathrm{H}, J=2.0 \mathrm{~Hz}), 6.82(\mathrm{dd}, 1 \mathrm{H}, J=2.0,8.0 \mathrm{~Hz}), 6.59$ (d, $1 \mathrm{H}, J=8.0 \mathrm{~Hz}$ ), $5.18(\mathrm{~d}, 1 \mathrm{H}, J=1.5 \mathrm{~Hz}), 2.74$ (h, $1 \mathrm{H}, J=7.0 \mathrm{~Hz}), 1.95$ (d, $3 \mathrm{H}, J=1.5 \mathrm{~Hz}), 1.91-1.85$ (m, $2 \mathrm{H})$, 1.69-1.52 (m, $4 \mathrm{H}), 1.17$ (d, $6 \mathrm{H}, J=6.9 \mathrm{~Hz}), 1.14-1.11$ (dq, $1 \mathrm{H}, J=4.4,13.7 \mathrm{~Hz}), 0.85$ (d, $3 \mathrm{H}$, $J=6.4 \mathrm{~Hz}$ ), 0.87-0.80 (m, $2 \mathrm{H}) ;{ }^{13} \mathrm{C}$ NMR (126 MHz, $d 4$-methanol):) 141.3, 137.7, 129.9, 128.9, 125.5, 122.6, 120.8, 113.6, 53.1, 45.7, 36.1, 34.0, 33.4, 26.3, 23.4, 21.8, 20.0, 17.4; IR (KBr, cm1) 3409 (m), 3018 (m), 2951 (s), 2940 (s), 2921 (s), 2918 (s), 2885 (s), 2866 (s), 2844 (s), 1650 (m), $1610(\mathrm{~s}), 1582$ (s), 1500 (s), 1455 (s), 1418 (m), 1378 (m), 1361 (m), 1331 (m), 1285 (s), 1264 (m), 1203 (m), 1178 (m), 1151 (m), 1053 (m), 1046 (m), 958 (s), 885 (m), 809 (m), 645 (w), 533 (w); MS (FI) 269 (M+1 100): Analysis $\left(\mathrm{C}_{19} \mathrm{H}_{27} \mathrm{~N}, 269.42\right)$ Calcd: $\mathrm{C}, 84.70 \%$; H, 10.10\%; N, 5.20\%. Found: C, 84.56\%; H, 9.89\%; N, 5.08\%.

Data for 22b: $R_{f}=0.47$ (hexane/ether, $\left.6 / 1\right) ;[\alpha]_{\mathrm{D}}+32\left(\mathrm{c}=1.52, \mathrm{CHCl}_{3}\right) ;{ }^{1} \mathrm{H}$ NMR $(500$ MHz, d4-methanol): $6.86(\mathrm{~d}, 1 \mathrm{H}, J=1.8 \mathrm{~Hz}), 6.83(\mathrm{dd}, 1 \mathrm{H}, J=2.0,8.2 \mathrm{~Hz}), 6.50(\mathrm{~d}, 1 \mathrm{H}, J=$ $8.0 \mathrm{~Hz}$ ), 5.72 (d, $1 \mathrm{H}, J=1.4 \mathrm{~Hz}), 2.73$ (h, $1 \mathrm{H}, J=6.9 \mathrm{~Hz}), 1.97$ (s, $3 \mathrm{H}), 1.99-1.95$ (m, $2 \mathrm{H})$, 
1.65-1.64 (m, 2 H), 1.57-1.54 (m, 2 H), $1.19(\mathrm{~d}, 6 \mathrm{H}, J=7.1 \mathrm{~Hz}), 1.20-1.13$ (m, $1 \mathrm{H}), 0.84$ (d, $3 \mathrm{H}$, $J=6.4 \mathrm{~Hz}$ ), 0.87-0.82 (m, $2 \mathrm{H})$; ${ }^{13} \mathrm{C}$ NMR (126 MHz, $d 4$-methanol):) 143.3, 139.2, 130.8, 127.1, $126.7,124.0,122.4,114.9,54.6,39.7,35.8,34.8,30.1,29.8,23.1,22.7,19.2 ; \mathrm{IR}\left(\mathrm{KBr}, \mathrm{cm}^{-1}\right)$ 3362 (m), 3019 (m), 2953 (s), 2949 (s), 2939 (s), 2923 (s), 2919 (s), 2888 (s), 2865 (s), 2843 (s) 1645 (s), 1610 (s), 1581 (s), 1499 (s), 1461 (s), 1455 (s), 1379 (s), 1361 (s), 1347 (s), 1331 (s), 1290 (s), 1252 (m), 1244(m), 1219 (m), 1203 (m), 1190 (m) 1178 (m), 1151 (m), 1106 (s) 1069 (s), $1055(\mathrm{~s}), 954(\mathrm{~m}), 884(\mathrm{~m}), 810(\mathrm{~m}), 646(\mathrm{w}), 573$ (m); MS (FI) 269 (M $\left.\mathrm{M}^{+}, 100\right)$ : Analysis

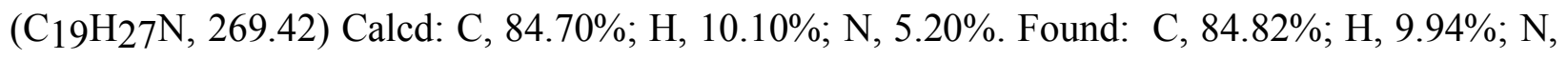
$5.30 \%$.

\section{Mass spectral analysis of natural abundance quinolines 22}

\begin{tabular}{|ccccc|}
\hline $\begin{array}{c}\text { quinoline } \\
\text { source }\end{array}$ & $m / z$ & $268, \%$ & $m / z$ & $269, \%$ \\
$m / z$ & $270, \%$ & $m / z$ & $271, \%$ \\
\hline \hline run 1 & 0.0 & 100.0 & 23.0 & 2.5 \\
run 2 & 0.2 & 100.0 & 21.0 & 2.3 \\
run 3 & 0.2 & 100.0 & 22.5 & 2.5 \\
average & 0.2 & 100.0 & 22.2 & 2.5 \\
normalized & 0.1 & 80.1 & 17.8 & 2.0 \\
\hline
\end{tabular}

Double Label Cross Over Experiment with Synthetic Pulegone. A solution of pulegone (100 mg, $0.65 \mathrm{mmol})$, with a mass distribution of $\mathrm{M}^{+} /(\mathrm{M}+1)^{+} /(\mathrm{M}+2)^{+} /(\mathrm{M}+3)^{+}$ 44.0\%:4.2\%:1.5\%:45.2\%), 4-isopropylaniline (67 mg, $0.5 \mathrm{mmol}$ and iodine (10.0 $\mathrm{mg}, 0.02$ mmol, $4 \mathrm{~mol} \%)$ in toluene $(1 \mathrm{~mL})$ was heated at reflux for $8 \mathrm{~h}$. After $3 \mathrm{~h}$ the reaction mixture was replenished with toluene $(0.5 \mathrm{~mL})$ and iodine $(3 \mathrm{mg})$. The reaction mixture was concentrated in vacuo and the residue was chromatographed on $\mathrm{SiO}_{2}$ (ether/pentanes 1:24) to isolate two diastereomers of quinoline (26.8 mg, $26.4 \mathrm{mg} \mathrm{30.4 \% )} \mathrm{as} \mathrm{a} \mathrm{colorless} \mathrm{oil.} \mathrm{The} \mathrm{unreacted} \mathrm{pulegone}$ was also isolated $(66 \mathrm{mg}, 66 \%)$. The ${ }^{1} \mathrm{H}$ and ${ }^{13} \mathrm{C}$ NMR data of both the unreacted pulegone and quinoline products were identical to those from the literature. The mass distribution of the unreacted pulegone and quinoline diastereomers were evaluated by FI mass spectrometry. 
Mass spectral analysis of recovered pulegone.

\begin{tabular}{|c|c|c|c|c|c|}
\hline $\begin{array}{c}\text { pulegone } \\
\text { source } \\
\end{array}$ & $\begin{array}{c}m / z 152 \\
\% \\
\end{array}$ & $\begin{array}{c}m / z 153 \\
\% \\
\end{array}$ & $\begin{array}{c}m / z 154 \\
\% \\
\end{array}$ & $\begin{array}{c}m / z 155 \\
\% \\
\end{array}$ & $\begin{array}{c}m / z 156, \\
\% \\
\end{array}$ \\
\hline $\begin{array}{c}\text { cross over experiment } \\
\text { pulegone recovered }\end{array}$ & 44.0 & 4.2 & 1.5 & 45.2 & 5.1 \\
\hline run 1 & 84.4 & 11.1 & 3.6 & 100.0 & 9.0 \\
\hline run 2 & 85.9 & 11.1 & 3.5 & 100.0 & 9.1 \\
\hline run 3 & 98.5 & 13.0 & 3.8 & 100.0 & 10.6 \\
\hline run 4 & 97.7 & 14.7 & 3.7 & 100.0 & 10.6 \\
\hline average & 91.6 & 12.5 & 3.7 & 100.0 & 9.8 \\
\hline normalized & 42.1 & 5.7 & 1.7 & 46.0 & 4.5 \\
\hline
\end{tabular}

\section{Mass spectral analysis of quinoline 22a}

\begin{tabular}{|cccccccc|}
\hline quinoline source & $m / z$ & $m / z$ & $m / z$ & $m / z$ & $m / z$ & $m / z$ & $m / z$ \\
& $268, \%$ & $269, \%$ & $270, \%$ & $271, \%$ & $272, \%$ & $273, \%$ & $274, \%$ \\
\hline \hline run 1 & 0.7 & 51.9 & 78.2 & 87.0 & 100.0 & 25.6 & 3.7 \\
run 2 & 0.4 & 58.8 & 87.2 & 94.3 & 100.0 & 30.2 & 4.1 \\
run 3 & 0.3 & 56.1 & 84.0 & 91.2 & 100.0 & 28.1 & 3.6 \\
average & 0.5 & 55.6 & 83.1 & 90.8 & 100.0 & 28.0 & 3.8 \\
normalized & 0.1 & 15.4 & 23.0 & 25.1 & 27.6 & 7.7 & 1.1 \\
Gauss-Jordan Analysis & --- & 19.7 & 25.3 & 26.2 & 28.8 & --- & -- \\
Theoretical 100\% scrambling & --- & 24.2 & 25.0 & 25.0 & 25.9 & --- & --- \\
\hline
\end{tabular}

Mass spectral analysis of quinoline 22b

\begin{tabular}{|cccccccc|}
\hline quinoline source & $m / z$ & $m / z$ & $m / z$ & $m / z$ & $m / z$ & $m / z$ & $m / z$ \\
& $268, \%$ & $269, \%$ & $270, \%$ & $271, \%$ & $272, \%$ & $273, \%$ & $274, \%$ \\
\hline \hline run 1 & 0.4 & 63.0 & 88.7 & 93.0 & 100.0 & 17.4 & 1.6 \\
run 2 & 0.4 & 68.1 & 94.6 & 97.0 & 100.0 & 17.8 & 1.6 \\
run 3 & 0.4 & 67.3 & 90.6 & 93.4 & 100.0 & 19.2 & 1.8 \\
average & 0.4 & 66.1 & 91.3 & 94.4 & 100.0 & 18.1 & 1.7 \\
normalized & 0.1 & 17.8 & 24.5 & 25.9 & 26.9 & 4.9 & 0.4 \\
Gauss-Jordan Analysis & --- & 21.9 & 25.6 & 25.4 & 27.1 & --- & --- \\
Theoretical 100\% scrambling & --- & 24.2 & 25.0 & 25.0 & 25.9 & --- & --- \\
\hline
\end{tabular}


Control experiment for pulegone scrambling. A solution of pulegone (32 $\mathrm{mg}, 0.20$ mmol, with a mass distribution of $\left.\mathrm{M}^{+} /(\mathrm{M}+1)^{+} /(\mathrm{M}+2)^{+} /(\mathrm{M}+3)^{+}: 45.2 \% / 3.8 \% / 1.3 \% / 44.6 \%\right)$ and iodine $(4.5 \mathrm{mg}, 0.01 \mathrm{mmol}, 5 \mathrm{~mol} \%)$ in toluene $(1 \mathrm{~mL})$ was heated at reflux for $8 \mathrm{~h}$. The reaction mixture was concentrated in vacuo and residue was purified by silica gel chromatography (pentane/ether, 24/1) to afford pulegone $\left(26 \mathrm{mg}, 87 \%\right.$ ) as a colorless oil. The ${ }^{1} \mathrm{H}$ and ${ }^{13} \mathrm{C}$ NMR data were identical to those from a previously synthesized sample. The FI mass distribution is shown below.

\section{Mass spectral analysis of recovered pulegone}

\begin{tabular}{|cccccc|}
\hline $\begin{array}{c}\text { pulegone } \\
\text { source }\end{array}$ & $\begin{array}{c}m / z 152, \\
\%\end{array}$ & $\begin{array}{c}m / z 153, \\
\%\end{array}$ & $\begin{array}{c}m / z 154, \\
\%\end{array}$ & $\begin{array}{c}m / z 155, \\
\%\end{array}$ & $\begin{array}{c}m / z 156, \\
\%\end{array}$ \\
\hline \hline $\begin{array}{c}\text { control experiment } \\
\text { pulegone recovered }\end{array}$ & $\mathbf{4 5 . 2}$ & $\mathbf{3 . 8}$ & $\mathbf{1 . 3}$ & $\mathbf{4 4 . 6}$ & $\mathbf{5 . 1}$ \\
run 1 & 100.0 & 15.3 & 4.6 & 88.2 & 10.1 \\
run 2 & 89.5 & 16.5 & 4.7 & 100.0 & 11.4 \\
run 3 & 93.1 & 13.4 & 3.8 & 100.0 & 7.5 \\
average & 94.2 & 15.1 & 4.4 & 96.1 & 9.7 \\
normalized & $\mathbf{4 2 . 9}$ & $\mathbf{6 . 9}$ & $\mathbf{2 . 0}$ & $\mathbf{4 3 . 8}$ & $\mathbf{4 . 6}$ \\
\hline
\end{tabular}

Synthesis of 2-Isopropenyl-4-isopropylaniline (29). A solution of bromide 27 (600 mg, 2.4 mmol), 2-isopropenyltributyltin (792 mg, $2.4 \mathrm{mmol}), \mathrm{PdCl}_{2}\left(\mathrm{PPh}_{3}\right)_{2}(168 \mathrm{mg}, 0.024 \mathrm{mmol} 10$ mol\%) in dioxane $(20 \mathrm{~mL})$ was freeze-thaw degassed and heated at reflux for $18 \mathrm{~h}$. The reaction mixture was cooled and filtered through a plug of Celite to remove the palladium black. The filtrate was concentrated in vacuo and at $40{ }^{\circ} \mathrm{C}$ and the residue was purified by silica gel chromatography (hexanes/EtOAc, 7/3) to yield 28 (440 mg, $84 \%$ ) as a colorless oil.

A solution of the acetamide $28(1.80 \mathrm{~g}, 8.3 \mathrm{mmol})$ in $60 \mathrm{~mL}$ of ethanol/water $(1: 1 \mathrm{v} / \mathrm{v})$ was treated with solid $\mathrm{KOH}$ (5.20 g, $92 \mathrm{mmol}, 10$ equiv) and heated at reflux under $\mathrm{N}_{2}$ for $48 \mathrm{~h}$. The reaction mixture was cooled to room temperature and diluted with ether $(100 \mathrm{~mL})$. The organic layer was separated in a separatory funnel and the aqueous layer was extracted with ether $(3 \times 30 \mathrm{~mL})$. The combined organic layers were dried $\left(\mathrm{Na}_{2} \mathrm{SO}_{4}\right)$, concentrated in vacuo. and purified by chromatography (silica gel, hexanes/EtOAc, 9/1) to afford $1.05 \mathrm{~g}(72 \%)$ of the 29 as a colorless oil: bp: $150^{\circ} \mathrm{C}\left(0.1 \mathrm{~mm} \mathrm{Hg}, R_{f} 0.42\right.$ (hexanes/EtOAc, 6/1): ${ }^{1} \mathrm{H}$ NMR (500 MHz, 
$\left.\mathrm{CDCl}_{3}\right): 6.97(\mathrm{dd}, J=6.5 \mathrm{~Hz}, 1 \mathrm{H}), 6.92(\mathrm{~s}, 1 \mathrm{H}, J=1.6,5.0 \mathrm{~Hz}), 6.68(\mathrm{~d}, 1 \mathrm{H}, J=8.2 \mathrm{~Hz}), 5.31$ (d, $J=0.9 \mathrm{~Hz}, 1 \mathrm{H}), 5.08$ (dd, $1.0 \mathrm{~Hz}, 0.9 \mathrm{~Hz}) ; .74$ (bs, $2 \mathrm{H}), 2.81$ (s, $J=6.3 \mathrm{~Hz}, 1 \mathrm{H}), 2.10$ (d, $J=0.7 \mathrm{~Hz}, 3 \mathrm{H}), 1.23$ (d, $J=6.3 \mathrm{~Hz}, 6 \mathrm{H}): 13 \mathrm{CNMR}\left(125 \mathrm{MHz}, \mathrm{CDCl}_{3}\right): 143.8,140.65,138.8$, 129.3, 126.2, 125.8, 115.7, 115.2, 33.3, 24.3, 24.0. IR (KBr): 3454, 3379, 3078, 3013, 2869 , $1618,1598,1500,1460,1449,1434,1422,1382,1371,1362,1326,1310,1300,1270,1158,901$, 818, 630, 579 MS (FI) $175\left(\mathrm{M}^{+}, 100\right)$. Analysis $\left(\mathrm{C}_{12} \mathrm{H}_{17} \mathrm{~N}\right)$ Calcd: $\mathrm{C}, 82.23 \%$; H, 9.73\%; N, 7.99\%. Found: C, 82.29\%; H, 9.48\%; N, 7.73\%.

\section{References}

(1) Still, W. C.; Kahn, M.; Mitra, A. J. Org. Chem. 1978, 43, 2923-2925.

(2) Gilman, H.; Cartledge, F. K. J. Organometal. Chem. 1964, 2, 447-454.

(3) Frangopol, M.; Genunche, A.; Negoita, N.; Frangopol, P. T.; Balaban, A. T. Tetrahedron 1967, 23, 841-844.

(4) (a) Wayne, W.; Adkins, H. Org. Synth. 1941, 21, 8-10. (b) Wayne, W.; Adkins, H. J. Am. Chem. Soc. 1940, 62, 3401-3404.

(5) Corey, E. J.; Chen, R. H. K. Tetrahedron Lett. 1973, 39, 3817-3820.

(6) Sterling, E. C.; Bogert, M. T. J. Org. Chem. 1939 4, 20-28. 